\title{
Optimisation of accounting model of inventory management in the textile industry
}

DOI: $10.35530 / 1 T .072 .02 .1769$

IVAN MILOJEVIĆ

SNEŽANA KRSTIĆ

MIHAILO ĆURČIĆ

\section{ABSTRACT - REZUMAT}

\section{Optimisation of accounting model of inventory management in the textile industry}

The supply system consists of several elements, which in their characteristics are distinguished in the overall structure of the supply system. They are defined uniquely in accordance with the function they perform, and in reality they appear at all levels of the budget system organization. Functioning of the supply system is possible only with the existence of certain inventories or reserves of material assets. The stocks represent the prescribed and determined quantities of material assets stored in the warehouses in order to ensure the normal functioning of the institutions.

Using the supplies management accounting model in textile industry is providing a continuous provision of equipment. This is essential to reach the adequate level of competence, which is in line with autonomous budget financing companies. Taking into account the specificity of the institutions, with an emphasis on the quality of the equipment, there is also the possibility for savings in maintaining them.

The aim of this paper is to present how the inventory management accounting system can optimize costs in the textile industry due to the full satisfaction of the optimal supply criterion.

Keywords: textile, management, accounting, model, supplies, efficiency

\section{Optimizarea modelului contabil de gestionare a stocurilor în industria textilă}

Sistemul de aprovizionare este format din mai multe elemente care, prin caracteristicile lor, se disting în structura generală a sistemului. Ele sunt definite în mod unic în conformitate cu funcția pe care o îndeplinesc și, în realitate, ele apar la toate nivelurile organizării sistemului bugetar. Funcționarea sistemului de aprovizionare este posibilă numai cu existența anumitor stocuri sau rezerve de active materiale. Stocurile reprezintă cantitățile prescrise și determinate de active materiale existente în depozite, pentru a asigura funcționarea normală a instituțiilor. Utilizarea modelului contabil de gestionare a consumabilelor în industria textilă oferă o furnizare continuă de echipamente. Acest lucru este esențial pentru a atinge nivelul adecvat de competență, în conformitate cu organizațiile autonome de finanțare bugetară. Ținând seama de specificul instituțiilor, cu accent pe calitatea echipamentelor, există și posibilitatea de a economisi în scopul întreținerii acestora. Scopul acestei lucrări este de a prezenta modul în care sistemul contabil de gestionare a stocurilor poate optimiza costurile în industria textilă datorită satisfacției depline a criteriului optim de aprovizionare.

Cuvinte-cheie: textil, management, contabilitate, model, consumabile, eficiență

\section{INTRODUCTION}

The stock of supplies is carried out periodically according to the plan of supply or demand as needed, as well as direct purchase, where it is necessary to keep a record of the level of inventory level. When completing the supply [1] with the purchase from the market, it is particularly important to pay attention to the choice of the supplier, i.e. to the ability of the supplier to deliver the goods and services of the required quality in accordance with the agreed deadlines. In the textile industry [2], this is particularly important for the successful performance of work and the performance of other tasks, where it is necessary to prepare certain quantities and a range of material resources that will be spent [3].

A particularly important source of funds is material reserves that are provided and are limited by the material possibilities of the textile industry [4, 5], so that the level of reserves changes according to the material possibilities, the state policy, and the degree of social and economic development of the state. Material reserves are planned and maintained at certain levels of organization of the state in accordance with the economic possibilities and needs of the textile market. The material reserves are planned and maintained at the appropriate level in accordance with economic opportunities and needs. There is a possibility of increasing them by intensive industrial production and imports. At certain levels of organization [6] of the state, the amount and structure of material reserves are determined in accordance with the law and according to special plans.

This paper is contained in four different parts. After "Methods of Modeling" where are defined the exact ways of upcoming research, we presented the "Modeling Results" of it. Once we had had the data, we have discussed them, at the "Discussion" part of the paper. At the very end, we drew a conclusion, and bulleted all the used references in this research. 


\section{METHODS OF MODELING}

The costs that are the subject of our research [7] are related to the total costs of securing supplies [8] of spare materials. In order to solve such a problem, the minimization of these costs [9] requires prior formation of the appropriate mathematical model of inventories, and then by solving it, the minimum total cost of inventory is determined. In order to create such a methodical stock model it is necessary to fulfil certain conditions and assumptions [10]. In the given planning period $T$, the demand, which will be denoted by $x$, is a stochastic variable with the known law of probability $p(x)$. Costs per unit of supply, if they are purchased on a regular basis, are $C_{1}$. Costs per unit of stock, if purchased through the occurrence of defects, are $C_{2}$. Costs can also be included in these costs due to lack of supplies. In practice, it is usual that $C_{2}$ costs are significantly higher than the cost of $C_{1}$; Initial supplies are equal to zero.

If $x$ is marked with demand, and $y$ with the level of inventory, then: if it is $x \leq y$, that is, if the level of inventory is higher than demand, then the costs of inventories will be paid $C_{1}(y-x)$; if $y>x$, that is, if the demand is higher than the available stocks, then the costs of extraordinary or urgent purchases which are $C_{2}(x-y)$. Taking into consideration that the demand $x$ is stochastic, and that the probability of a failure on the $p(x)$ agent is known, which means that the expected total costs will be obtained by adding the individual costs, for each $x$, multiplied by the corresponding probability $p(x)$ that the total cost function, denoted by $F(y)$, is reduced to the expected value, can be written in the following form:

$$
F(y)=C_{1} \sum_{x=0}^{y}(y-x) p(x)+C_{2} \sum_{x=y+1}^{\infty}(x-y) p(x)
$$

In order to determine the minimum expected total cost for this stock problem, it is necessary to determine the minimum of this function. Starting from the fact that this model refers to the provision of spare parts of assets, the minimization of this function will be assumed if the variables can be taken only by discrete and integer non-negative values. In this case, if there is some value in $y^{*}$, where the previously mentioned function takes its minimum value, the following condition must be fulfilled:

$$
F\left(y^{*}-1\right)>F\left(y^{*}\right)<F\left(y^{*}+1\right)
$$

If the functions $F(y-1)$ and $F(y+1)$ are formed, then the conditions under which $y=y^{*}$ will be determined. Starting from the function 1 in which the variable is replaced by $y-1$, it gets:

$$
\begin{gathered}
F(y-1)=C_{1} \sum_{x=0}^{y-1}(y-1-x) p(x)+C_{2} \sum_{x=y}^{\infty}(x-y+1) p(x) \\
F(y-1)=C_{1} \sum_{x=0}^{y-1}(y-x) p(x)+C_{2} \sum_{x=y}^{\infty}(x-y) p(x)- \\
-C_{1} \sum_{x=0}^{y-1} p(x)+C_{2} \sum_{x=y}^{\infty} p(x)
\end{gathered}
$$

Based on the relationship of function $F(y)$ and $F(y-1)$, a connection can be established between functions which can be written in the form of the following double inequality:

$$
p\left(x \leq y^{*}-1\right)<\frac{C_{2}}{C_{1}+C_{2}}<p\left(x \leq y^{*}\right)
$$

This means that if there is some value in $y^{*}$ that minimizes the function of the expected total cost, then in $y^{*}$ it must fulfil the conditions by the given equation 5 . The equation 5 is important not only because it determines the optimal conditions that the variable must fulfil, but also because it can also determine the optimal value of the stock in $y^{*}$ which minimizes the expected cost of the stock. This is achieved by first forming a table in which one line, or one column, represents the probability cumulative $p(x=y)$, and then, based on the known values for $C_{1}$ and $C_{2}$, the quotient is calculated:

$$
k=\frac{C_{2}}{C_{1}+C_{2}}
$$

After that in a row or column, the probability cumulative is determined by the values of the coefficient $\mathrm{k}$. Each of these cumulative probabilities $p(x=y)$ corresponds to one value in $y$. This value for $y$, which corresponds to a higher value of cumulative probabilities, represents the required optimal solution in $y^{*}$. Using the equation 5 , an optimal solution can also be performed, that is, the limits within which the costs of $C_{1}$ and $C_{2}$ can be determined without the change of the optimum solution:

$$
\begin{aligned}
& C_{1}<\frac{p\left(x \geq y^{*}\right)}{p\left(x \leq y^{*}-1\right)} \\
& C_{1}>\frac{p\left(x \geq y^{*}+1\right)}{p\left(x \leq y^{*}\right)}
\end{aligned}
$$

because

$$
p\left(x \leq y^{*}\right)=1-p\left(x>y^{*}\right)=1-p\left(x \geq y^{*}+1\right)
$$

The inequalities 7 and 8 can be combined into one double inequality of the form

$$
\frac{p\left(x \leq y^{*}+1\right)}{p\left(x \leq y^{*}\right)} C_{2}<C_{1}<\frac{p\left(x \geq y^{*}\right)}{p\left(x \leq y^{*}-1\right)} C_{2}
$$

which set the upper and lower limits within which the costs of $C_{1}$ can be moved, without changing the optimal solution. The lower and upper limits within which the costs of $C_{2}$ may be changed without affecting the change in the optimal solution are:

$$
\frac{p\left(x \leq y^{*}+1\right)}{1-p\left(x \leq y^{*}-1\right)} C_{1}<C_{2}<\frac{p\left(x \leq y^{*}\right)}{1-p\left(x \leq y^{*}\right)} C_{1}
$$

or otherwise written:

$$
\frac{p\left(x \leq y^{*}+1\right)}{p\left(x \geq y^{*}\right)} C_{1}<C_{2}<\frac{p\left(x \leq y^{*}\right)}{p\left(x \geq y^{*}+1\right)} C_{1}
$$

\section{MODELING RESULTS}

We determined by means of a weighted arithmetic mean method that the average cost of purchasing and storing spare materials [11] of technical means 
because this value for $y$ corresponds to a higher cumulative probability.

THE PROBABILITY OF REPLACEMENT OF SPARE MATERIALS

\begin{tabular}{|l|c|c|c|c|c|c|c|c|}
\hline $\begin{array}{l}\text { Number of spare } \\
\text { materials replaced } \boldsymbol{x}\end{array}$ & 0 & 1 & 2 & 3 & 4 & 5 & 6 & 7 \\
\hline $\begin{array}{l}\text { The probability of } \\
\text { replacement } \boldsymbol{p}(\boldsymbol{x})\end{array}$ & 0 & 0.25 & 0.30 & 0.20 & 0.10 & 0.10 & 0.05 & 0 \\
\hline
\end{tabular}

\section{DISCUSSION}

By obtaining the result, we confirmed the assumption that regular supply [15] was supposed during the purchase of the funds itself, when the supplier timely performed the service of delivery of the spare materials, amounted to $C_{1}=1,500 €$ for one spare material. In the period when the supplier did not deliver spare materials when purchasing the asset, the occurrence of the defect, the period of placing the asset out of use using the weighted arithmetic mean method, it was two months in length and the costs of emergency supplies [12] amounted to an average $C_{2}=6,000 €$. Through a population survey using the Poison's Distribution [13], the probability of replacing spare materials during the exploitation period of the observed assets has been obtained. These probabilities are shown in table 1.

Using a stochastic inventory model throughout the research population, we have set a relationship for solving the problem of determining the optimal size of the order of the spare material in $y^{*}$, in a regular way, for which the total cost of providing the stock will be minimal [14], and then determine the amount of these minimum costs and limits within which change the costs of $C_{1}$ and $C_{2}$, with the optimal solution remaining unchanged.

Starting from the initial quantities that we carried out in the research process based on the primary data $C_{1}=1,500 €$ and $C_{2}=6,000 €$ we get the value of the parameter $k$, which shows the share of the price of the spare material, that spare material was not delivered when buying the asset in the total price.

$$
k=\frac{6,000}{1,500+6,000}=0.8
$$

Starting from the assumption that Poison's probability distribution, the sample share of the entire population is obtained as a cumulative probability parameter; we performed the calculation in the table 2 .

Based on the data from the cumulative probability table $p(x \leq y)$, we obtained

$$
0.75<k<0.85
$$

which means it is:

$$
y^{*}=4
$$

to provide $y^{*}=4$ spare materials [16], and with a $85 \%$ probability, we can claim that the amount of 4 units of spare materials that is obtained is sufficient to eliminate all defects on the asset being monitored, while it is assumed the risk of $15 \%$ that one or two spare materials will be procured by emergency supplies in the event of a lack of supplies [17], which in any case in an emergency situation represents an insufficient level of probability of reliability of the purchase of spare materials [18]. In that case, the minimum costs would be

$$
\begin{gathered}
F\left(y^{*}=4\right)=1,500 \sum_{x=0}^{4}(4-x) p(x)+ \\
+6,000 \sum_{x=5}^{\infty}(4-x) p(x) \\
F\left(y^{*}=4\right)=1,500(3 \cdot 0.25+2 \cdot 0.30+1 \cdot 0.20)+ \\
+6,000(1 \cdot 0.10+2 \cdot 0.05)=3,525 €
\end{gathered}
$$

A mathematical check of the minimum costs of purchasing a spare material is carried out so that the optimal result is reduced by 1 , i.e. the magnification by $1, F\left(y^{*}-1=3\right)$ and $F\left(y^{*}+1=5\right)$ :

$$
\begin{gathered}
F(3)=1,500(2 \cdot 0.25+2 \cdot 0.30)+ \\
+6,000(1 \cdot 0.10+2 \cdot 0.10+3 \cdot 0.05)=3,900 €
\end{gathered}
$$

and

$$
\begin{gathered}
F(5)=1,500(4 \cdot 0.25+3 \cdot 0.30+2 \cdot 0.20+1 \cdot 0.10)+ \\
+6,000(1 \cdot 0.05)=3,900 €
\end{gathered}
$$

How it was checked that it was:

$$
F(3)>F(4)<F(5)
$$

these are, indeed, for $y^{*}=4$, the minimum costs, and therefore the boundary of the cost changes $C_{1}$ and $C_{2}$, for which there will be no change in the optimal solution. These boundaries are determined by equations 8 and 12, which means that the boundary of the cost change $C_{1}$ is valid

$$
\frac{p(x \geq 5)}{p(x \leq 4)} \cdot 6,000<C_{1}<\frac{p(x \geq 4)}{p(x \leq 3)} \cdot 6,000
$$

PROBABILITY AND CUMULATIVE PROBABILITY OF REPLACEMENT OF SPARE PARTS

\begin{tabular}{|c|c|c|c|c|c|c|c|c|}
\hline $\mathbf{y}$ & 0 & 1 & 2 & 3 & 4 & 5 & 6 & 7 \\
\hline $\mathbf{x}$ & 0 & 1 & 2 & 3 & 4 & 5 & 6 & 7 \\
\hline $\mathbf{p}(\mathbf{x})$ & 0 & 0.25 & 0.30 & 0.20 & 0.10 & 0.10 & 0.05 & 0 \\
\hline $\mathbf{p}(\mathbf{x} \leq \mathbf{y})$ & 0 & 0.25 & 0.55 & 0.75 & 0.85 & 0.95 & 1.00 & 1.00 \\
\hline
\end{tabular}




$$
\frac{0.15}{0.85} \cdot 6,000<C_{1}<\frac{0.25}{0.75} \cdot 6,000
$$

from where the required limits for changing the cost of $C_{1}$ are ultimately determined:

$$
1,058.82<C_{1}<2,000.00
$$

The same as in the previous case, the limits in which the costs of $C_{2}$ can be moved without changing the optimal solution $y^{*}=4$, are:

$$
\frac{0.75}{0.25} \cdot 1,500<C_{2}<\frac{0.85}{0.15} \cdot 1,500
$$

from where it gets:

$$
4,500.00<C_{2}<8,500.00
$$

The verification of the obtained solutions is carried out by assuming that the first is that $C_{1}=1200$, and then that $C_{1}=1,890$. In the first case it is:

$$
k=\frac{6,000}{1,200+6,000}=0.8333
$$

in the other:

$$
k=\frac{6,000}{1,890+6,000}=0.7604
$$

So, in both cases it is

$$
0.75<k<0,85
$$

which means that the mentioned changes in the cost of $C_{1}$ do not affect the change of the optimal solution. A similar check can also be done for the costs of $C_{2}$, which means that the changes and costs of $C_{2}$ will not lead to the change of the optimal solution $y^{*}=4$.

\section{CONCLUSION}

In the conducted research, we have shown that savings could be achieved by timely procurement and delivery of an optimal quantity of spare parts $y^{*}=4$ by suppliers, over $€ 12,000$ in the probability of a failure in the observed assets of $85 \%$. In this case, there was a risk with a $15 \%$ probability of failure and there is no pre-supplied spare part. On the other hand, the existence of inventories would speed up the correction of the asset as soon as possible, which would reduce the time of the inaccuracy of the observed asset and further influence the adequate equipment of the institution with equipment, which is a very important element for the textile industry. Using this model, it would be possible to continuously provide the equipment for textile industry, which is crucial for the successful achievement of the appropriate level of competence, and of particular importance for textile companies that work on the principle of autonomous budget financing.

\section{ACKNOWLEDGEMENTS}

This research is a part of the project no. VA-DH5/17-19 Development of the financial service of the Army of Serbia from 1985 to 2015, financed by the Ministry of Defense of the Republic of Serbia. Project period: 2016-2020.

\section{REFERENCES}

[1] Rao, C.M., Rao, K.P., Muniswamy, V.V., Delivery Performance Measurement in an Integrated Supply Chain Management: Case Study in Batteries Manufacturing Firm, In: Serbian Journal of Management, 2011, 6, 2, 205-220

[2] Bruce, M., Daly, L., Towers, N., Lean or agile: A solution for supply chain management in the textiles and clothing industry, In: International Journal of Operations \& Production Management, 2004, 24, 2, 15-170

[3] Aureo, B., Razvoj računovodstva, In: Oditor - časopis za Menadžment, finansije i pravo, 2016, 2, 3, 39-48

[4] Koyuncu, I., Kural, E., Topacik, D., Pilot scale nanofiltration membrane separation for waste management in textile industry, In: Water \& Science Technology, 2001, 43, 10, 233-240

[5] Chen, L., Yan, X., Yu, H., Developing a modular apparel safety architecture for supply chain management: the apparel recycle perspective, In: Industria Textila, 2018, 69, 1, 24-30, http://doi.org/10.35530/IT.069.01.1380

[6] Zhao, M., Nichols, T., Management Control of Labour in State-Owned Enterprises: Cases From the Textile Industry, In: The China Journal, 1996, 36, 1-21

[7] Lambert, D.M., Cooper, M.C., Pagh, J.D., Supply Chain Management: Implementation Issues and Research Opportunities, In: The International Journal of Logistics Management, 1998, 9, 2, 1-20

[8] Cooper, M.C., Lambert, D.M., Pagh, J.D., Supply Chain Management: More Than a New Name for Logistics, In: The International Journal of Logistics Management, 1997, 8, 1, 1-14

[9] Prdić, N., Konkurentska prednost preduzeća na osnovu benčmarking analize poslovanja, In: Oditor - časopis za Menadžment, finansije i pravo, 2017, 3, 3, 107-117

[10] Backović, M., Vuleta, J., Popović, Z., Ekonomsko-matematički metodi i modeli, Centar za izdavačku delatnost: Ekonomski fakultet, Beograd, 2014

[11] Thomas, D.J., Griffin, P.M., Coordinated supply chain management, In: European Journal of Operational Research, 1996, 94, 1, 1-15

[12] Mentezer, J.T., DeWitt, W., Keebler, J.S., Min, S., Nix, N.W., Smith, C.D., Zacharia, Z.G., Defining supply chain management, In: Journal of Business Logistics, 2001, 22, 2, 1-25

[13] Žižić, M., Lovrić, M., Pavličić, D., Metodi statističke analize, Centar za izdavačku delatnost: Ekonomski fakultet, Beograd, 2003

[14] Nuševa, D., Marić, R., Quick Response Logistics in Retailing as an Information Technology Based Concept, In: Strategic Management, 2017, 22, 4, 32-38

[15] Olateju, O.E., Fabson, T.V.O., A Comparative Study of Simulation and Time Series Model in Quantifying Bullwhip Effect in Supply Chain, In: Serbian Journal of Management, 2011, 6, 2, 145-154 
[16] Hilletofth, P., Hilmola, O-P., Supply chain management in fashion and textile industry, In: International Journal of Services Sciencies, 2008, 1, 2, 127-147

[17] Koprulu, A., Albayrakoglu, M.M., Supply chain management in the textile industry: A supplier selection model with the analytical hierarchy process, In: ISAHP, 2007

[18] Lambert, D.M., Cooper, M.C., Issues in Supply Chain Management, In: Industrial Marketing Management, 2000, $29,1,65-83$

\section{Authors:}

IVAN MILOJEVIĆ, SNEŽANA KRSTIĆ, MIHAILO ĆURČIĆ

University of Defence, Military Academy, Public Finance Department,

Pavla Jurišića Šturma 33, 11000, Belgrade, Serbia

e-mail: drimilojevic@gmail.com, snezanakrstic17@gmail.com

\section{Corresponding author:}

MIHAILO ĆURČIĆ, Ph.D.

e-mail: curcicmihailo@gmail.com 